\title{
DISABILITY MILESTONES IN HUNTINGTON DISEASE
}

\section{MILJOKAZI PROGRESIJE HUNTINGTONOVE BOLESTI}

\author{
Jelena Ćuk², Ana Đuranović2, Marina Svetel ${ }^{1,2}$, Tatjana Pekmezović, ${ }^{12}$
}

\section{Summary}

Huntington's disease (HD) is an autosomal dominant neurodegenerative disease which is characterized by the presence of involuntary choreatic movements, cognitive impoverishment and behavioral disorders.

The objectives of this research were: analysis of the clinical specifics of people with HD and definition of chronology in the occurrence of milestone disease progression.

56 patients with HD were interviewed by telephone about their age, family history, age at onset of the disease, first symptoms, current symptoms and their beginning. Also, the number of trinucleotide (CAG) repeats was determined by PCR method.

In group of 50 alive patients the average age was 54.5 years, age at the beginning of disease 46.7 years, disease duration 7.8 years and latency to diagnosis 2 years, approximately. Family history was positive for 22 patients. Most frequently first symptoms were involuntary movements as isolated symptom (24 patients). In a progression of the disease swallowing difficulty and choking were first problem in everyday life for patients and they occurred 4.5 years after the first symptoms. Talking difficulty, falls, dependence on the assistance of another person during bathing and eating and walking difficulty happened after 4.6, 5.2, 6.2, 7.5 and 7.5 years, respectively. The average number of trinucleotide repeats was 43.8, in range from 40 to 51 repeats.

HD in short term leads to significant disability with the emergence of problems with swallowing, speaking and walking, leading thus to complete depending on the physical assistance of another person.

Keywords: Huntington disease, progression, chorea, trinucleotide repeats

\section{Sažetak}

Huntingtonova bolest je autozomno dominantna neurodegenerativna bolest koja se karakteriše nevoljnim pokretima, kognitivnim osiromašenjem i poremećajem ponašanja.

Ciljevi istraživanja su analiza kliničke specifičnosti pacijenata sa Hantingtonovom bolesti i definisanje hronologije u razvoju miljokaza progresije bolesti.

Pedeset i šest pacijenata je intervjuisano telefonski i dobijeni su podaci o njihovoj starosti, porodičnoj anamnezi, starosti na početku bolesti, prvim simptomima i trenutnim simptomima kao i o trenutku njihovog nastanka. Takođe, broj trinukleotidnih CAG ponovaka je ispitan PCR metodom.

U našoj grupi ispitanika od 50 živih pacijenata prosečna starost je iznosila 54,5 godina, starost na početku bolesti 46,7 godina, trajanje bolesti 7,8 godina a latenca do postavljanja dijagnoze 2 godine. Porodična anamneza je bila pozitivna za 22 bolesnika. Najčešći prvi symptom bili su nevoljni pokreti kao izolovan symptom (24 bolesnika). U daljoj progresiji bolesti problem sa gutanjem i zagricnjavanje su bili prvi problem koji je otežavao bolesnicima svakodnevni život i pojavio se u proseku za 4,5 godina posle prvog simptoma. Problemi sa gutanjem, padanje, zavisnost od drugih osoba prilikom kupanja i jela, otežano hodanje desili su se posle 4,6; 5,2; 6,2; 7,5 i 7,5 godina, redom. Broj trinukleotidnih ponovaka se kretao od 40 do 51 , u proseku 43.8.

Hantingtonova bolest u kratkom vremenskom period dovodi do značajne onesposobljenosti sa nastankom problema pri gutanju, pričanju i hodanju, dovodeći potom do potpune zavisnosti od fizičke pomoći druge osobe.

Ključne reči: Hantingtonova bolest, horea, pregoresija, trinukleotidni ponovci

\section{INTRODUCTION}

Huntington's disease (HD) is an autosomal dominant neurodegenerative disease which is characterized by the presence of involuntary choreatic movements, cognitive impoverishment and behavioral disorders (1).

The prevalence of HD is $3-7$ on 100000 residents in Western Europe. It rarely appears in Japan, China, Finland and Africa, so the frequency of HD in Japan is from 0.1 to 0.38 per 100000 inhabitants, while the prevalence in some populations of Western European origin exceeds 15 per 100000 (2). Due to the isolation of the population frequency of HD on Lake Marakoibo in Venezuela is 700 per 100000 (3).
Choreatic movements, by which it got its name, are typical for the disease but dystonia can also be recorded, later incoordination of movements with immobility, bradykinesia and rigidity in the final stages of the disease. These symptoms are associated with a damage of cognitive functions such as attention and memory, as well as psychiatric symptoms, including personality changes, depression, psychosis and dementia that often precede motor symptoms. Other symptoms, including weight loss, muscle atrophy, cardiac dysfunction, and testicular atrophy, as well as endocrine abnormalities that become evident with a progression of the disease (4).

The gene responsible for HD is located on 4 p16.3 locus. In that gene multiple repetitions of the CAG triplet nu- 
cleotides (cytosine, adenine, guanine) occur, encoding implantation of the amino acid glutamine in the protein called hantingtin (5). Forty and more repetitions are associated with the expression of the disease. If there are 36 to 39 repeats, penetrance of mutation is reduced, so some carriers will manifest the disease, and some will not (6).

The brain in the final stage of the disease is $400 \mathrm{~g}$ lighter compared to the average weight of 1300-1400g $(7,8)$. This atrophy is the result of an extensive atrophy in the caudate nucleus and in putamen, but it is also a result of a serious neuron loss in deeper layers of the cerebral cortex (9). The hippocampus and the thalamus are also affected, but cerebellum significantly less. White mass, including the corpus callosum is hypotrophic (10). The loss of cortical neurons leads to cognitive and behavioral problems (11).

In the treatment of HD tetrabenazine is used and it lowers vesicular depots of catecholamine, a drug that suppresses chorea and is associated with global clinical improvement (12). Neuroleptic drugs which block the postsynaptic dopamine receptors, fluphenazine (13), and haloperidol (14) can be effective in the suppression of chorea. It is considered that taking tricyclic antidepressants and serotonin reuptake inhibitors can improve the condition of HD patients (15).

\section{AIM}

The objectives of our research were:

1. Analysis of the clinical specifics of people with HD

2. Definition of chronology in the occurrence of milestone disease progression

\section{MATERIALS AND METHODS}

There were 56 patients who participated in the research all of whom were diagnosed with Huntington's disease through the neurological examination at the Neurology Clinic of the Clinical Center of Serbia. The diagnosis was based on clinical findings, positive family history, and confirmed with the analysis of trinucleotid repeats in IT 15 gene.

Patients were informed of the study over the telephone when they were asked if either them or the members of their family could answer the questions from an open questionnaire. The questionnaire collected data on the patient's age, family history related to $\mathrm{HD}$, the age of the patient at the time of diagnosis and at the time of occurrence of the first symptoms. The patients were also questioned about the type of their first symptoms. Further, patients and their family members gave information about the current clinical picture and about the problems associated with speaking, swallowing and chewing, walking, falling, mood, sleeping, appetite and weight changes. It is also tested whether the patient can independently feed, bath, go out of the house, do the housework and if he/she uses diapers, catheter or wheelchairs. Apart from all these symptoms, data were also given about when the symptoms first appeared, in relation to the occurrence of the first symptoms.

After data collection, answers from the patients or their family members were grouped and analyzed statistically.

In addition to the questionnaire, in the research we have also covered data on the number of trinucleotide CAG repeats by PCR method. Blood samples were taken from all patients to determine the number of CAG repeats in a known manner (16). Briefly, genomic DNA was isolated from peripheral blood samples using standard procedures which including proteinase $\mathrm{K}$ and phenol chloroform insulation. Polymerase chain reaction (PCR) was performed with the primers: HC-1 (5'-ATG GCC TTC AAG TCC CTC AAG GAG TCC TCC3 ') and HC-2 (5'-CAG CAG CTG CGG TGCBCTG-3'). The amplification was performed in $25-\mathrm{ml}$ reaction mixture which contained 1 X PCR buffer (Pharmacia), $200 \mathrm{mM}$ each dNTPs, $1.5 \mathrm{mM} \mathrm{Mg} 2 \mathrm{Cl}, 100 \mathrm{ng}$ of each primer, $5 \%$ glycerol (final concentration), $1 \mathrm{U}$ of Taq polymerase (Pharmacia) and $200 \mathrm{ng}$ of genomic DNA. Terms of the cycle were: $3 \mathrm{~min}$. Initial denaturation at $97^{\circ} \mathrm{C}$, followed with 35 cycles of $1 \mathrm{~min}$ at $95^{\circ} \mathrm{C}, 1 \mathrm{~min}$ at $60^{\circ} \mathrm{C}$ and $2 \mathrm{~min}$ at $72^{\circ} \mathrm{C}$, and the final $10 \mathrm{~min}$ at $72^{\circ} \mathrm{C}$. Samples were first analyzed on $2 \%$ agarose gel. For determination of the precise number of CAG repeats part of each reaction (7 $\mathrm{mL})$ was mixed with $3 \mathrm{ml}$ of buffer $(0.25 \%$ bromophenol blue, $0.25 \%$ xylene cianol in $100 \%$ formamide) and denatured with heat at $100^{\circ} \mathrm{C}$ for $10 \mathrm{~min}$ before adding to $6 \%$ poliakrilamid- urea denaturing gel. Samples were electrophoresis in $0.5 \mathrm{X}$ TBE buffer. The product of amplification was detected by silver staining using the standard procedure. In our laboratory the genes which contain at least 40 repeats confirm the diagnosis of HD.

\section{Results}

The research included 56 patients with the diagnosis of Huntington's chorea confirmed also by genetic testing. Of the contacted patients ten have died, and for the six of the dead families were not willing to give any information. There were 19 men and 37 women. At the time of the telephone interviews, patients were aged $54.45 \pm$ 9.61 (25-74) years, and at the time when the first symptoms appeared they were $46.69 \pm 10.37$ (23-65) years. We did not get the data on family history from $10 \mathrm{pa}-$ tients, whose families have not been informed of any relatives with the same disease. For 11 patients family history was allegedly negative with frequent data of early deaths of one or both parents, for 7 it was insecure 
Table 1. Clinical and demographic specifics of patients with Huntington's disease

\begin{tabular}{|c|c|}
\hline Male/Female & $19: 37$ \\
\hline Age $^{*}$ & $54.45 \pm 9.61(25-74)$ \\
\hline Alive $\infty$ & $50 / 56(82,1)$ \\
\hline Trinucleotide repeats number ${ }^{\star}$ & $43.87(40-51)$ \\
\hline Age at onset* & $46.69 \pm 10.37(23-65)$ \\
\hline Latency to diagnosis* & $1.90 \pm 2.87(0-12)$ \\
\hline Disease duration ${ }^{*}$ & $7.81 \pm 5.18(0-28)$ \\
\hline \multirow{6}{*}{$\begin{array}{l}\text { First symptoms } \infty \\
\text { Involutary movements } \\
\text { Involuntary movements, walking difficulty, instability, falls } \\
\text { Involuntary movements, aggressiveness, agitation, anxiety } \\
\text { Involuntary movements, depression } \\
\text { Other }\end{array}$} & \\
\hline & $24 / 49(42,9)$ \\
\hline & $5 / 49(8.9)$ \\
\hline & $4 / 49(7.1)$ \\
\hline & $2 / 49(3.6)$ \\
\hline & $14 / 49(25)$ \\
\hline \multirow{4}{*}{$\begin{array}{c}\text { Family history } \infty, \\
\text { No data } \\
\text { Negative } \\
\text { Uncertain } \\
\text { Positive }\end{array}$} & $10 / 50(20)$ \\
\hline & $11 / 50(22.5)$ \\
\hline & $7 / 50(14)$ \\
\hline & $22 / 50(44)$ \\
\hline
\end{tabular}

*average value with SD and range in a parenthesis; $\infty$ number of patients (percentage)

(there are relatives with similar symptoms who are not diagnosed and treated), and for 22 patients family history for HD was positive (in 9 cases mother was ill, and in 13 that was the case with the father).

The average age in the beginning of the disease for patients whose mother was ill was $42.55 \pm 7.35$ years, for those with diseased father $45.67 \pm 6.62$ years, and for patients with a negative family history of HD 50.1 \pm 10.14 years. There is no statistically significant difference between the age at the begging of the disease for patients who have inherited disease from the mother and patients who inherited the disease from father. Also, although the disease occurred later in patients with a negative family history, compared to those with positive family history, this difference was not shown to be statistically significant. The number of trinucleotide repeats in our patients ranged from 40 to 51. Clinical demographic characteristics of the patients are shown in Table 1.

Involuntary movements were first, isolated symptoms for 24/49 patients, while the occurrence of walk disorder at the same time, with instability, falling and sticking was observed in 5 patients. In 4 patients aggressiveness, anxiety and nervousness were manifested along with the involuntary movements, and in 2 that was a case with depression. Other symptoms (absence, obliviousness, cognitive disorders, facial tics, swallowing disorders and /or speaking, dizziness, disturbance of sphincter control and psychiatric symptoms in the form of delusions) occurred in 14 patients alone or in combination.

In specified telephone interview patients' family members gave information that in the current clinical picture involuntary movements occurred in 45 patients. In five patients involuntary movements were not pres- ent. Walk which is either difficult and requires help or is impossible was characteristic of 23/50 patients, while 20 patients were falling. Nearly $80 \%$ (39/50) of patients choked, and slightly higher percentage of them spoke with difficulty and incomprehensibly (42/50). In 34 patients mood change was recorded, of which 12 patients are depressive, reticent and recluse, 10 are anxious or aggressive, 7 have a changeable mood, and 2 are oblivious. The combination of anxiety, aggressiveness and obliviousness occurred in another 3 patients. Sleeping problems were found in 28 patients, most commonly in the form of early morning awakening and getting up frequently during the night (11 patients). Three patients reported that their sleep quality reduced because of the great anxiety during sleeping. Seven patients put themselves to sleep only with the help of sleeping pills, while 5 patients say that their need for sleep increased. Appetite is reduced in nine patients, and increased in four, while 29 patients lost weight. 23/50 patients depend on feeding and require help; 32/50 do not conduct their own hygiene; 35/50 do not leave the house, while ten go out periodically, often with the help in the walks. There are 38 patients who cannot perform, seven use diapers, one patient uses catheter and six wheelchairs (Figure 1).

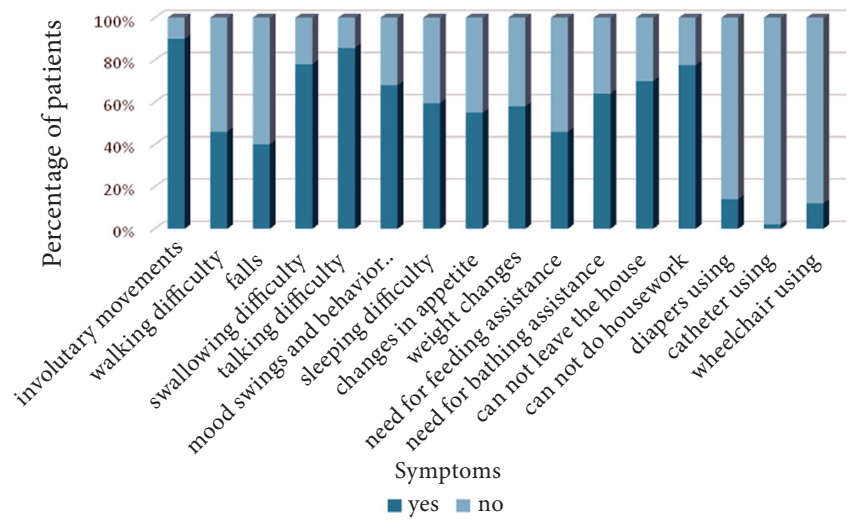

Figure 1. Huntington disease symptoms representation 
Table 2. Milestones in progression of Huntington disease

\begin{tabular}{|ll|}
\hline Milestone & $\begin{array}{l}\text { Years after first symptom } \\
\text { (average value } \pm \text { SD) }\end{array}$ \\
\hline Swallowing difficulty & $4.45 \pm 4.02$ \\
\hline Talking difficulty & $4.58 \pm 3.01$ \\
\hline Falls & $5.25 \pm 4.02$ \\
Need for bathing assistance & $6.22 \pm 4.05$ \\
Need for feeding assistance & $7.47 \pm 4.27$ \\
\hline Walking difficulty & $7.53 \pm 4.63$ \\
Catheter using & $9 \pm 0$ \\
\hline Diapers using & $9.11 \pm 3.68$ \\
Wheelchair using & $10 \pm 6.54$
\end{tabular}

Listed symptoms and status patients reached out in a short period of time (Table 2). The earliest evolved interferences with swallowing, chewing and speech, and the latest complete immobility with the attachment to the wheelchair (Figure 2).

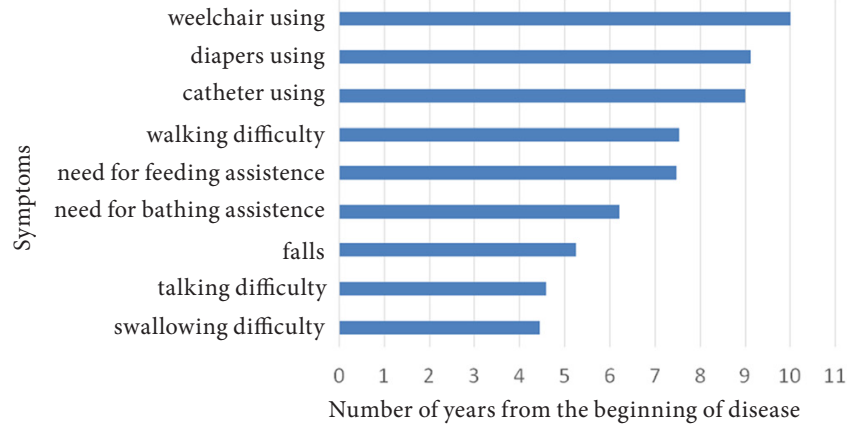

Figure 2. Milestones in progression of Huntington disease

\section{Discussion}

Although it is known that Huntington's disease equally affects men and women, the sex ratio of the patients included in our study was almost 2: 1 in favor of women (37:19). These results can be explained by the fact that women are major participants in studies on subjects under the risk for $\mathrm{HD}$, as well as being more likely to require predictive genetic analysis for $\operatorname{HD}(17,18,19)$. Also, it is known that women with Huntington's disease live longer, which could be another explanation for why there are more women in random sample (20).

The first symptoms in our patients were reported on average of 46.7 years of age, which is consistent with many other studies that indicate that the first symptoms occur in the 4 th and 5 th decade of life (21). Our youngest patient was 23 years old at the beginning of the disease, and the oldest was 65 years old, which fits the range of 8 to 83 years in other studies (22).

Of the total of 50 interviewed patients, $22 \mathrm{had}$ a positive family history, of which 9 patients inherited disease from the mother and 13 from the father. It is known that sex of the parents does not affect the heriditet because HD is an autosomal dominant disease, and it is transmitted on $50 \%$ of the offspring (23). Significant difference was not shown between the age at diagnosis in our patients who have inherited the disease from their mother and patients who have inherited the disease from their father, which is in accordance with the results of the study from Venezuela (24).

A quarter of our surveyed patients, more precisely 11 of them have a negative family history of HD. It is interesting that our results are consistent with research conducted in British Columbia, in which also a quarter of patients had a negative family history. In $7.8 \%$ of the total number of patients in the same research it is proved or probable de novo mutations due to the instability of CAG repeats (25).

The first symptom in our patients were involuntary movements (in 24 patients independently and in other 11 patients they were associated with other symptoms). These results were expected, due to the fact that other studies had shown that in the diagnostic stage chorea is the first and most evident sign of the disease (23). Changes in mood and behavior, including aggression, agitation, nervousness, depression, absence, obliviousness, cognitive disorders, as well as psychotic signs such as hallucinations and paranoia are reported in 15 of our patients as the symptoms with which the disease began. It is known that these symptoms often precede the motor signs of the disease, but are often ignored or attributed to other causes $(5,26)$.

Latency of developing the first symptoms to diagnosis lasted for an average of about 2 years, although the longest latency was even 12 years long. This is common for patients with HD, especially if their involuntary movements are weakly expressed, the patient do not notice them or denies them, or they do not interfere with patients daily activities (on face, as in our patient).

With an average of 4.5 years after the appearance of first symptoms, patients have begun to swallow with difficulty, to chew and have spasms during meals, and shortly after that they started to speak difficult and incomprehensible. Our patients developed problems with speech much earlier than most patients in a similar research (27) where this symptom appeared between 6 and 10 years after the beginning of the disease. A year later, the patients would usually begin to fall, which would interfere with the independent walk and led to difficult and disabled walk for about 2 years, or 7.5 years after the beginning of the disease. Results of the research show that with the majority of patients problems with walking occurred in the period of 5-6 years from the beginning of the disease. Six to seven years since the beginning of the disease, patients are hampered in their daily activities such as eating and hygiene of the body and require help in performing them. Loss of the sphincter control our patients developed for an average of 9 years, which is a bit earlier than the majority of patients in the research mentioned above, in which urinary incontinence emerged after 10 years. 


\section{Conclusion}

Huntington's chorea is a chronic progressive disease that in the short term it leads to significant disability with the emergence of problems with swallowing, speaking and walking, leading then to complete depending on the physical assistance of another person.

\section{References}

1. Dayalu P, Albin RL. Huntington disease: pathogenesis and treatment. Neurologic Clinics 2015; 33: 101-14.

2. Bates G, Harper P, Jones L. Huntington's Disease. New York: Oxford University Press; 2002.

3. Avila-Giron R. Medical and Social Aspects of Huntington's Chorea in the State of Zulia, Venezuela. In: Barbeau A, Chase TN, Paulson GW, eds. Advances in Neurology. New York: Raven Press; 1973. p. 261-66.

4. Novak MJU, Tabrizi SJ. Huntington's disease: Clinical presentation and treatment. International Review of Neurobiology 2011; 98: 297-323

5. The Huntington's disease collaborative research group. A novel gene containing a trinucleotide repeat that is expanded and unstable on Huntington's disease chromosomes. Cell 1993; 72(6): 971-83.

6. Myers, RH. Huntington's Disease Genetics. NeuroRx 2004; 1(2): 255-62.

7. Vonsattel J, Myers R., Stevens T, Ferrante R, Bird E, Richardson E. Neuropathological classification of Huntington's disease. Journal of neuropathology and experimental neurology 1995; 44(6): 559-77.

8. Keller C, Del Pilar Amaya M. Neuropathology of Huntington's disease. In: Vinken PJ, Bruyn GW, eds. Handbook of Clinical Neurology. Amsterdam: Elsevier: 2008. p. 599-618.

9. Aucoin JS, Jiang P, Aznavour N, Tong XK, Buttini M, Descarries L, Hamel E. Selective cholinergic denervation, independent from oxidative stress, in a mouse model of Alzheimer's disease. Neuroscience 2005; 132(1): 73-86.

10. Hersch S, Gevorkian S, Marder K, Moskowitz C, Feigin A, Cox M, et al. Creatine in Huntington disease is safe, tolerable, bioavailable in brain and reduces serum 8OH2'dG. Neurology 2006; 66(2): 250-52.

11. DiFiglia M, Sapp E, Chase KO, Davies SW, Bates GP, Vonsattel JP, et al. Aggregation of huntingtin in neuronal intranuclear inclusions and dystrophic neurites in brain. Science 1997; 277(5334): 1990-3.

12. Huntington Study Group. Tetrabenazine as antichorea therapy in Huntington disease: a randomized controlled trial. Neurology 2006; 66(3): 366-72.

13. Fahn S. Perphenazine in Huntington's chorea. In: Barbeau A, Chase TN, Paulson GW, eds. Advances in Neurology: Huntington's Chorea. New York: Raven Press; 1973. p. 1872-972.

14. Leonard DP, Kidson MA, Shannon PJ, Brown J. Letter: Doubleblind trial of lithium carbonate and haloperidol in Huntington's chorea. Lancet 1974; 2(7890): 1208-9.
15. Bonelli RM, Wenning GK. Pharmacological management of Huntington's disease: an evidence-based review. Cur Pharm Des 2006; 12(21): 2701-20.

16. Culjkovic B, Ruzdijic S, Rakic LJ, Romac S. Improved PCR conditions for quick diagnostics of Huntington's disease. Brain Res Protocols 1997; 2(1): 44-6.

17. Tibben A. Genetic counseling and presymptomatic testing. In: Bates G, Harper P, Jones L, eds. Huntington's Disease. 3rd ed. New York: Oxford University Press; 2002. p. 198-248.

18. Kirkwood SC, Siemers E, Hodes ME, Conneally PM, Christian JC, Foroud T. Changes among presymptomatic Huntington disease gene carriers. J Neurol Neurosurg Psychiatry 2000; 69(6): 773-9.

19. The Huntington Study Group PHAROS Investigators. At Risk for Huntington Disease The PHAROS (Prospective Huntington At Risk Observational Study) Cohort Enrolled. Arch Neurol 2006; 63(7): 991-6.

20. Pekmezovic T, Svetel M, Maric J, Dujmovic-Basuroski I, Dragasevic N, Keckarevic M, et al. Survival of Huntington's disease patients in Serbia: longer survival in female patients. Eur J Epidemiol 2007; 22(8): 523-6.

21. Frank S. Treatment of Huntington's Disease. Neurotherapeutics 2014; 11(1):153-60.

22. Mahant N, McCusker EA, Byth K, Graham S. Huntington's disease: clinical correlates of disability and progression. Neurology 2003; 61(8): 1085-92.

23. Walker FO. Huntington's disease. Lancet 2007; 369(9557): 218-28.

24. Penney J, Young S. Huntington's Disease in Venezuela: 7 Years of Follow-up on Symptomatic and Asymptomatic Individuals. Movement Disorders 1990; 5(2): 93-9.

25. Semaka A, Creighton S, Warby S, Hayden M. Predictive testing for Huntington disease: interpretation and significance of intermediate alleles. Clinical Genetics 2006; 70(4): 283-94.

26. Kremer B. Clinical neurology of Huntington's disease: diversity in unity, unity in diversity. In: BatesbG, Harper P, Jones L, eds. Huntington's Disease. 3rd ed. New York: Oxford University Press: 2002. p. 28-61.

27. Kirkwood S, Su JL, Conneally P, Foroud T. Progression of symptoms in the early and middle stages of Huntington disease. Arch Neurol 2001; 58(2): 273-8. 